\title{
Late Silurian plutons in Yucatan
}

\author{
M.B. Steiner \\ Department of Geology and Geophysics, University of Wyoming, Laramie
}

\author{
J. Douglas Walker \\ Isotope Geochemistry Laboratory and Department of Geology, University of Kansas, Lawrence
}

\begin{abstract}
U-Pb measurements of zircons from two composite plutons in the Maya Mountains of the Yucatan Block (Belize) give Late Silurian ages. Zircons from one of the five compositional phases of the Mountain Pine Ridge pluton yield an age of $418 \pm 3.6 \mathrm{Ma}$. A second compositional phase gives a minimum age of $404 \mathrm{Ma}$, and zircons from a third phase, although plagued with high common $\mathrm{Pb}$, yield ages consistent with the other two. Zircons from one compositional phase of the Hummingbird-Mullins River pluton indicate an age of about 410-420 Ma. These data demonstrate that two of the three Maya Mountains plutons residing among the strata of the Late Pennsylvanian through Permian Santa Rosa Group are older than that sedimentation. Although the third pluton was not dated, both the similarity of sedimentary facies patterns adjacent to it to those adjacent to one of the plutons dated as Late Silurian and a published single $\mathbf{R b}-\mathrm{Sr}$ age of 428+41 Ma suggest this third pluton also was emergent during Santa Rosa deposition. Thus the new $\mathrm{U} / \mathrm{Pb}$ dates and other data suggest that all three Maya Mountains plutons pre-date Late Carboniferous sedimentation and that none intrude the Santa Rosa Group. Although very uniform ages of about $230 \mathrm{Ma}$ amongst all plutons, derived from abundant earlier dating by the $\mathrm{K}$-Ar system, led to the conclusion that intrusion mostly had occurred in the Late Triassic, the $\mathrm{U}-\mathrm{Pb}$ ages (obtained from the same sites as the $\mathrm{K}-\mathrm{Ar}$ dates) demonstrate that the $\mathrm{K}$-Ar ages do not derive from a Late Triassic intrusive episode. The K-Ar dates probably are a signature of the rifting associated with Pangean breakup and formation of the Gulf of Mexico. In a reconstructed Pangea, the position of the Maya Mountains Late Silurian plutons suggests that the Late Silurian Acadian-Caledonian orogen of eastern North America extended through the region of the future Gulf of Mexico. Finally, the U-Pb ages of the Maya Mountains plutons are the same as those of a group of shocked zircons found in the Chicxulub impact structure and its fallout layer. The presence of these ages in both locations suggests that the Maya Mountains exposures may be representative of the basement of the Yucatan Block, hence of the basement impacted by the Chicxulub object.
\end{abstract}

\section{Introduction and Geologic Setting}

The Maya Mountains are a horst which provides one of the few exposures of pre-Cretaceous rocks of the Yucatan, or Maya, Block. The exposure is a west-southwest trending synclinorium of Permian and Pennsylvanian sedimentary strata enclosing three granitic plutons (Figure 1). The strata, the Santa Rosa Group, consist of sandstones, siltstones, mudstones, and shales with some limestone and conglomerate; volcanic rocks (ca. $300 \mathrm{Ma}$ ) interfinger with the deposits in some areas [Bateson and Hall. 1977]. Well-preserved fusulinids, mollusks, including ammonites, and brachiopods indicate that this sequence is Late Pennsylvanian through mid-Permian (late Leonardian) in age [Bateson and Hall. 1977; Ross, 1979]. The Santa Rosa Group has been folded and has experienced low grade regional metamorphism (lower greenschist facies) [Bateson and Hall, 1977].

Copyright 1996 by the American Geophysical Union.

Paper number 96JB00174.

0148-0227/96/96JB-00174\$09.00
The three plutons (Figure 1) enclosed by the sedimentary rocks are (1) the Mountain Pine Ridge (MPR) in the northwest Maya Mountains; (2) the Hummingbird-Mullins River (HMR) in the northeast; and (3) the Cockscomb and adjacent, probably attached [Bateson and Hall, 1977], Sapote stock (C/S) in the southeast. The MPR pluton is a composite of five bodies of different compositions: a diorite-granodiorite, granodiorite, quartz monzonite, granite, and muscovite granite. The HMR pluton consists of large bodies of two-mica granite adjacent to a large body of granodiorite, and a separate lobe of quartz monzonite. The Cockscomb pluton is a large single intrusive body of porphyritic biotite granite with accessory muscovite [Bateson and Hall, 1977; Cole and Andrews-Jones, 1979].

This investigation was undertaken to support a paleomagnetic study of the Pangean paleoposition of the Yucatan Block [Steiner, 1996], and in particular to resolve a conflict in existing radiometric ages. Published $\mathrm{Rb}-\mathrm{Sr}$ and $\mathrm{K}-\mathrm{Ar}$ ages from one of the plutons differ by $100 \mathrm{~m} . y$., while that pluton and the other two all give nearly identical $\mathrm{K}-\mathrm{Ar}$ ages. We therefore dated these granitic-composition Maya Mountains intrusives using the $\mathrm{U}-\mathrm{Pb}$ system. 


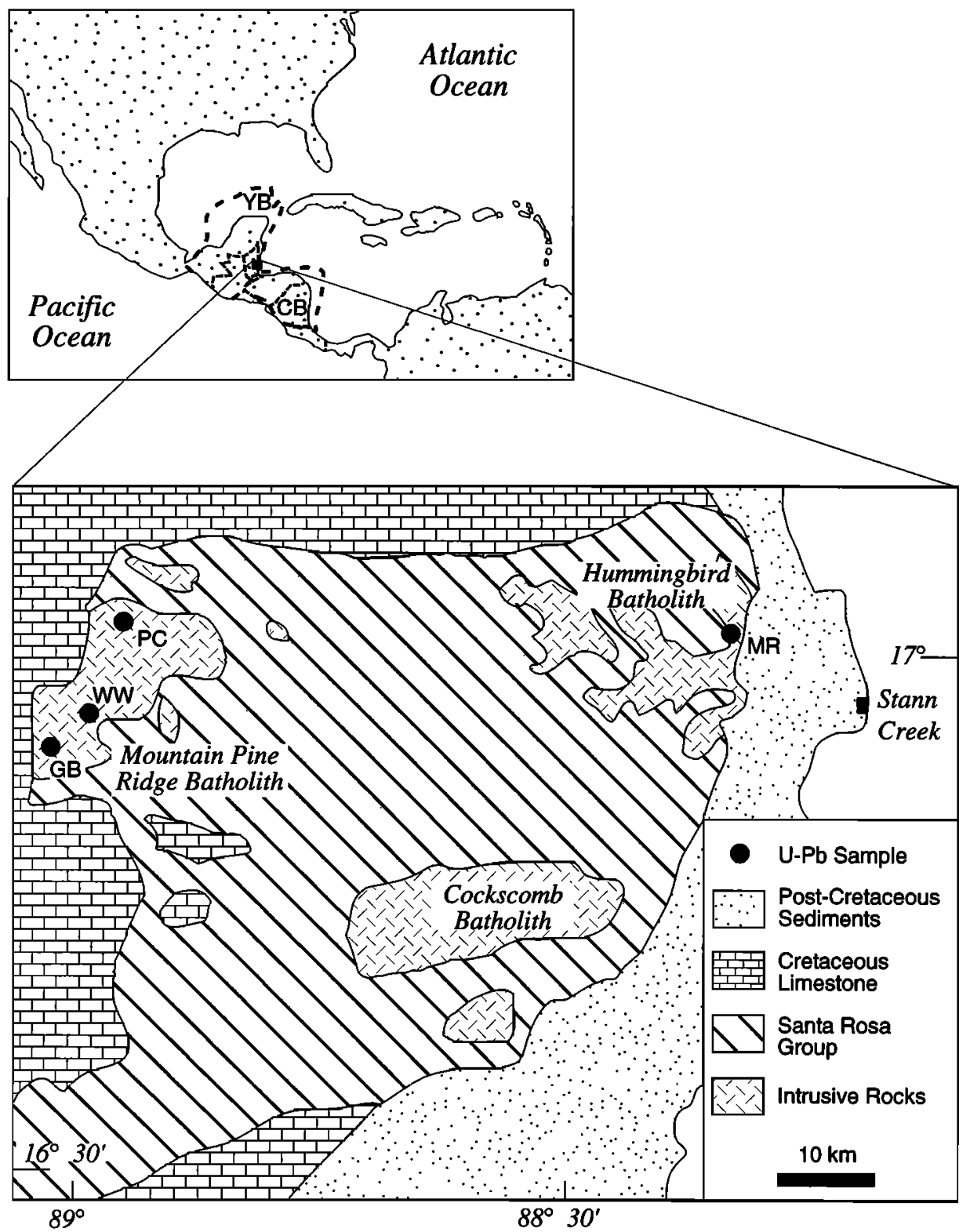

Figure 1. Location of the Maya Mountains and U-Pb sampling sites (geologic map modified from Bateson and Hall [1972], reprinted by permission). Abbreviations are YB, Yucatan Block; CB, Chortis Block; GB, Guacamallo Bridge sample; MR, Mullins River sample; PC, Privasson Creek sample; and WW, Windroad sample.

\section{Previous Work}

Each of the three plutons has had multiple radiometric age determinations by either one or two methods. Initially, the MPR pluton was dated by Rb-Sr, giving ages of 280-300 and $390 \mathrm{Ma}$ [Bateson, 1972; Kesler et al., 1974]. Later, a Rb-Sr whole-rock isochron age of $336 \pm 10 \mathrm{Ma}$ was obtained [Bateson and Hall, 1977, recalculated with the new decay constant by Dawe, 1984], but the scatter in the data and the fact that independent analyses of K-feldspars plotted below the isochron indicated that the $\mathrm{Rb}-\mathrm{Sr}$ system had been disturbed by a later event [Bateson and Hall, 1977]. Numerous K-Ar ages (biotite) also were determined for this pluton [Cole and Andrews-Jones, 1979], as well as for the other two plutons, the Sapote stock [Bateson and Hall, 1977], and one locality in the Bladen Volcanics [Cole and Andrews-Jones, 1979]. All K-Ar ages are remarkably uniform
(Table 1), clustering around an age of $230 \mathrm{Ma}$ (new decay constant). The uniformity of K-Ar ages from all of the plutonic rocks of the Maya Mountains is notable, as is the 100-m y. difference between the K-Ar and Rb-Sr ages in the same body.

In reconstructing Maya Mountains geologic history, attention has focused mainly on the Late Triassic K-Ar ages, principally because they are so uniform; Bateson and Hall [1977, p. 42] considered the uniformity as "prima facie evidence" of a Triassic intrusive age for the two eastern plutons. However, the eastern plutons have been dated only by the K-Ar method, with the exception of one Rb-Sr determination from the Sapote stock, a small intrusive body separated from the Cockscomb (C/S) pluton by $10 \mathrm{~km}$ and thought to be attached at depth. Bateson and Hall [1977] reported a single $\mathrm{Rb}-\mathrm{Sr}$ analysis with an age of $428 \pm 41$ Ma for the Sapote stock, but they dismissed this age as anomalous because their $\mathrm{K}-\mathrm{Ar}$ age for this body $(232 \pm 5 \mathrm{Ma})$ 
Table 1. K/Ar Ages of Maya Mountains Igneous Rocks

\begin{tabular}{lrrrrrrr}
\hline Igneous Body & \multicolumn{2}{c}{$\begin{array}{c}\text { Age as } \\
\text { Publıshed, Ma }\end{array}$} & $\begin{array}{c}\text { Recalculaled } \\
\text { Age }\end{array}$ & & $\begin{array}{c}\text { Material } \\
\text { Dated }\end{array}$ & Reference \\
\hline Mountain Pine Ridge & & $201 \pm 8$ & $(205)$ & & $*$ & 2 & 2 \\
Mountain Pine Ridge & $210 \pm 8$ & $(214)$ & & $*$ & & 2 & \\
Mountain Pine Ridge & $228 \pm 8$ & $(232)$ & & $*$ & & 2 & \\
Mountain Pine Ridge & $227 \pm 8$ & $(231)$ & & $*$ & & & \\
Hummingbird & & $227 \pm 7$ & $231 \pm 7$ & & biotite & 1,3 & \\
Humningbird & $223 \pm 7$ & $227 \pm 7$ & & biotite & & 1,3 \\
Cockscomb & & $222 \pm 7$ & $226 \pm 7$ & & biotite & & 1,3 \\
Sapote & $232 \pm 5$ & $237 \pm 5$ & & biotite & & 1,3 \\
Cockscomb & $226 \pm 8$ & $(230)$ & & $*$ & & 2,3 \\
Bladen Volcanics & & $232 \pm 8$ & $(236)$ & $*$ & & 2 \\
\hline
\end{tabular}

References are 1, Bateson \& Hall [1977] (recalculated by Dawe [1984]); 2, Cole and AndrewsJones [1979]; 3, Dawe [1984]. (Nol all data were available for recalculation, therefore extrapolations of these data to the new decay constant, based on the changes in the ages that were recalculated, are shown in the parentheses.) Asterisk denotes that type of material dated was not given.

agreed so well with the K-Ar ages of the adjacent Cockscomb pluton and the HMR pluton to the north. The Silurian Rb-Sr age also was rejected because no other Silurian-Ordovician rock ages were known in Belize [Bateson_and Hall, 1977; Cole and Andrews-Jones, 1979]. The presence of the same K-Ar ages in the western, MPR pluton as those in the eastern HMR and C/S plutons and the discrepancy between those $\mathrm{K}-\mathrm{Ar}$ ages and the $\mathrm{Rb}-\mathrm{Sr}$ ages of the MPR and C/S plutons strongly suggests that at least two of the Maya Mountains plutons may be older than indicated by the $\mathrm{K}-\mathrm{Ar}$ data.

In addition to the Late Triassic ages, thermal alteration of the metasedimentary rocks around the margins of the eastern plutons had been observed [Ower, 1928; Dixon, 1956; Bateson and Hall, 1977]. The alteration was confined to the sedimentary rocks in contact with pluton margins, superposed over the weak regional metamorphism. The altered zones were observed to contain prominent chiastolite (andalusite) [Ower, 1928; Dixon, 1956; Bateson and Hall, 1977]. The combination of observations were interpreted to indicate that the alteration was a contact metamorphism that was related to pluton intrusion [Ower, 1928; Dixon, 1956; Bateson and Hall, 1977]. The K-Ar ages led to the interpretation that intrusion had occurred in the Late Triassic [e.g., Bateson and Hall, 1977].

Studies initially reported the presence of contact metamorphism around all three plutons [Ower, 1928; Dixon, 1956; Bateson and Hall, 1977], however, a later study indicated that the alteration around the western, MPR pluton was a hydrothermal in origin [Dawe, 1984]. This hydrothermal alteration was observed at the pluton margins, both in the surrounding sedimentary sequence and along joints and fractures within the pluton [Dawe, 1984]. This study thus implicitly restricted to the eastern two plutonic bodies, the contact metamorphism interpreted as related to intrusion.

Initially, the combination of the apparent contact metamorphism and the $\mathrm{K}-\mathrm{Ar}$ ages led Maya Mountains investigators to conclude that emplacement of all plutons had occurred in the Late Triassic, but later the concept of Late Triassic intrusion was restricted to the eastern plutons and a portion of the western [Kesler et al., 1971; Hall and Bateson, 1972; Bateson and Hall, 1977; Shipley, 1978]. Generally, investigators have considered that this intrusive event was coeval with or postdated the folding and regional metamorphism of the sedimentary rocks. The common geologic scenario for the Maya Mountains consists of Permo-Carboniferous sedimentation accompanied by limited volcanism, followed by an episode of folding, and finally, Late Triassic granitic intrusion [Kesler et al., 1974; Bateson and Hall, 1977; Cole and Andrews-Jones, 1979; Dawe, 1984; Donmelly et al., 1990]. The timing of the folding was bracketed by the youngest faunal ages of the sedimentary rocks (mid-Permian) and the Late Triassic K-Ar ages of the granites. Folding thus was thought to be of Late Permian-Early Triassic age; in addition, this age appeared to be supported by the presence of an orogenic episode of that age which deformed a similar sedimentary sequence in Guatemala and rocks elsewhere in Central America [e.g., McBirney, 1963; Dengo and Bohnenberger, 1969].

The belief that intrusion was a postfolding event also was inferred to be supported by the fact that the folding deformation does not extend into the plutons [Bateson, 1972]. However, a tremendous difference in rock competency exists between the very fine grained, mostly pelitic Santa Rosa sediments and the massive, medium- to coarse-grained granitic plutons. As recently demonstrated by Paterson and Tobisch [1988], plutonic rocks do not necessarily record the obvious deformation displayed by surrounding sedimentary rocks, thus invalidating any support for the relative ages of deformation and intrusion in the Maya Mounains based on absence of igneous rock deformation.

The most recent work in the MPR pluton inferred that all five of the compositional phases of the western pluton were intruded prior to Santa Rosa sedimentation, at 336 Ma [Dawe, 1984], with subsequent deposition of the Pennsylvanian-Permian strata unconformably on these intrusives. In Dawe's interpretation, after the period of regional folding and metamorphism sometime between mid-Permian and Late Triassic, the MPR pluton experienced an episode of hydrothermal alteration and dike emplacement during the Late Triassic. He hypothesized that these events were related to the Late Triassic intrusion of the two eastern Maya Mountains plutons [Dawe, 1984; Donnelly et al., 1990].

Subsequent to Late Triassic time, the geologic history of the Maya Mountains was relatively simple. The region subsided and was blanketed by Mesozoic and Cenozoic sediments. Late Jurassic-earliest Cretaceous continental sediments (the Todos Santos Formation) were deposited on the deformed Santa Rosa 
Group, followed by a thick sequence of Cretaceous and Tertiary marine carbonates. Later uplift of the southern end of the Yucatan Block exposed the older rocks from beneath the Cretaceous-Tertiary cover.

\section{Geochronologic Results}

Samples were collected from three different compositional phases of the MPR pluton and from one phase of the HMR pluton (Figure $1 \mathrm{~b}$ ). MPR sites included a porphyritic granite sampled at Guacamallo Bridge on the Macal River, a dioritic to granodioritic composition pluton called the Windward Road pluton, and a granite sampled at Privasson Creek. The HMR pluton was sampled in the Mullins River granite and granite porphyry along the Mullins River. Samples were taken from the same localities from which published $\mathrm{K}-\mathrm{Ar}$ ages had been determined. Samples were sledge-hammered from river bed and creek exposures. Despite the tropical weathering environment, the samples were quite fresh, a result of the active erosion in the Maya Mountains. Abundant zircons were recovered from all four samples and were divided into fractions using magnetic susceptibility, size, and morphology (Table 2).

\section{MPR Pluton}

The U-Pb isotopic behavior of the zircon population from the Guacamallo Bridge site is simple. The zircons from the porphyritic granite appear to have suffered simple $\mathrm{Pb}$ loss, as $\mathrm{U}-\mathrm{Pb}$ data from three fractions give a linear array of discordant points (Figure $2 \mathrm{a}$ ). $\mathrm{Pb}-\mathrm{Pb}$ ages for all fractions are the same within error. We interpret the upper intercept age of $418 \pm 3.6 \mathrm{Ma}$ to be the age of crystallization of this sample [Ludwig, 1990, Model 1].

$\mathrm{U}-\mathrm{Pb}$ data of zircon fractions from the Windward Road granodiorite trend toward older ages away from concordia, in a pattern consistent with the incorporation of older, xenocrystic zircon (Figure 2b). The results of three bulk fractions give a lower intercept age of $403 \mathrm{Ma}$. To test for the effects of $\mathrm{Pb}$ loss, two handpicked fractions were air abraded. One of the points lies on the previously defined chord, while the other falls below the chord. We interpret these results to indicate that the lower intercept age of $404 \pm 3.3 \mathrm{Ma}$ (defined on the four colinear points) [Ludwig, 1990, Model 1] represents the crystallization age of this sample. We consider this a minimum age, however, because it is possible that the fractions suffered bulk $\mathrm{Pb}$ loss rather than loss merely confined to the outermost portions of the grains.

Results from the third site in the MPR pluton, the Privasson Creek granite, are uncertain due to the high concentration of common $\mathrm{Pb}$ in the zircons (Table 2). The ${ }^{206} \mathrm{~Pb} /{ }^{238} \mathrm{U}$ ages are in broad agreement, however, with the other results from this pluton (Table 2).

\section{HMR Pluton}

The Mullins River data are more poorly constrained than that of the MPR pluton, but are consistent with them. Five zircon and three monazite fractions were analyzed. It is apparent from the data that both $\mathrm{Pb}$ loss and an inherited component are present in the zircons from this rock (Figure $2 \mathrm{c}$ ). A chord from $410 \mathrm{Ma}$ to $1600 \mathrm{Ma}$ is shown for reference. Monazites from the sample show some evidence for $\mathrm{Pb}$ loss in that they scatter above, below, and along concordia. We take the age of $420 \mathrm{Ma}$, corresponding to the age of the oldest monazite grain, as the best estimate of the age of this sample. This age from the Mullins River body of the HMR pluton is entirely consistent with the zircon data and ages of the MPR pluton (Figures 2a, 2b).

\section{Discussion}

\section{Geologic Relationship of Plutons to Santa Rosa Group}

The Late Silurian ages for three of the five compositional phases of the MPR pluton and for the Mullins River body of the HMR pluton indicate that at least two of the three plutons of the Maya Mountains predate deposition of the sedimentary rocks of the Permo-Carboniferous Santa Rosa Group.

These ages suggest that the plutons may have been emergent at the time of sedimentation. In the Mountain Pine Ridge area, this inference is consistent with the striking abundance of conglomerate and sandstone in the Santa Rosa Group near the MPR pluton, in contrast to a general paucity of coarse-grained rocks in most of the Santa Rosa Group of the Maya Mountains [Dixon, 1956; Simmons, 1972; Bateson and Hall, 1977; Shipley, 1978]. Furthermore, although the Santa Rosa Group is dominantly gray in color, red sedimentary rocks reminiscent of typical "red beds" are abundant around the southern and eastern margins of this pluton [Simmons, 1972; Steiner, 1996]; the presence of red beds around the flanks of this pluton is readily consistent with subaerial weathering of an emergent granitic pluton in nearequatorial latitudes and subaerial or subaqueous deposition of the resultant materials adjacent to the pluton, while the predominantly gray Santa Rosa strata were being deposited further offshore.

Although our radiometric data only demonstrate that two of the three Maya Mountains intrusive bodies predate Pennsylvanian-Permian sedimentation, published geologic data suggest that the third intrusive (C/S pluton) also predates Santa Rosa Group deposition. The lithology of the Santa Rosa Group departs from a dominantly mudstone-shale grain size primarily in two areas of the Maya Mountains: one area is around the MPR pluton and the other is surrounding the $\mathrm{C} / \mathrm{S}$ pluton [see Bateson and Hall, 1975]. Sandstone associated with some conglomerate is abundant north and south of the C/S pluton [Dixon, 1956; Bateson and Hall, 1975, 1977]; furthermore, an unpublished report [Muncaster, 1976] described some red sedimentary facies to the south of the $\mathrm{C} / \mathrm{S}$ plutonic complex.

The radiometric age determinations from the MPR pluton confirm the implication from the coarser sedimentary facies adjacent to it that this pluton was emergent during Santa Rosa deposition; the similar facies pattern around the $\mathrm{C} / \mathrm{S}$ pluton likewise suggests that it also may have been emergent. Moreover, this inference derives support from the single non-K/Ar radiometric date associated with this pluton, the $\mathrm{Rb}-\mathrm{Sr}$ age of $428 \pm 41 \mathrm{Ma}$ from the Sapote Stock [Bateson and Hall, 1977]. Although this date was discarded at the time because of lack of any other evidence of Silurian age rocks in the Maya Mountains, it certainly agrees with our Late Silurian ages for the MPR and HMR plutons, suggesting that this age may be more reasonable than has been thought. Therefore, albeit tentatively, evidence from two independent sources suggests that the third Maya Mountains pluton (C/S) also may be older than the Late Carboniferous-Early Permian deposition in this area. Thus, it appears that all three Maya Mountains intrusives may predate the enclosing sedimentary strata.

\section{The 230 Ma Event}

Our ages for the MPR pluton refine existing data [Bateson and Hall, 1977], and the similarity of the ages from the different compositional phases of the MPR pluton imply that all of the multiphase body was intruded in the Late Silurian and none of the phases were intruded in Late Triassic time. Our data also 


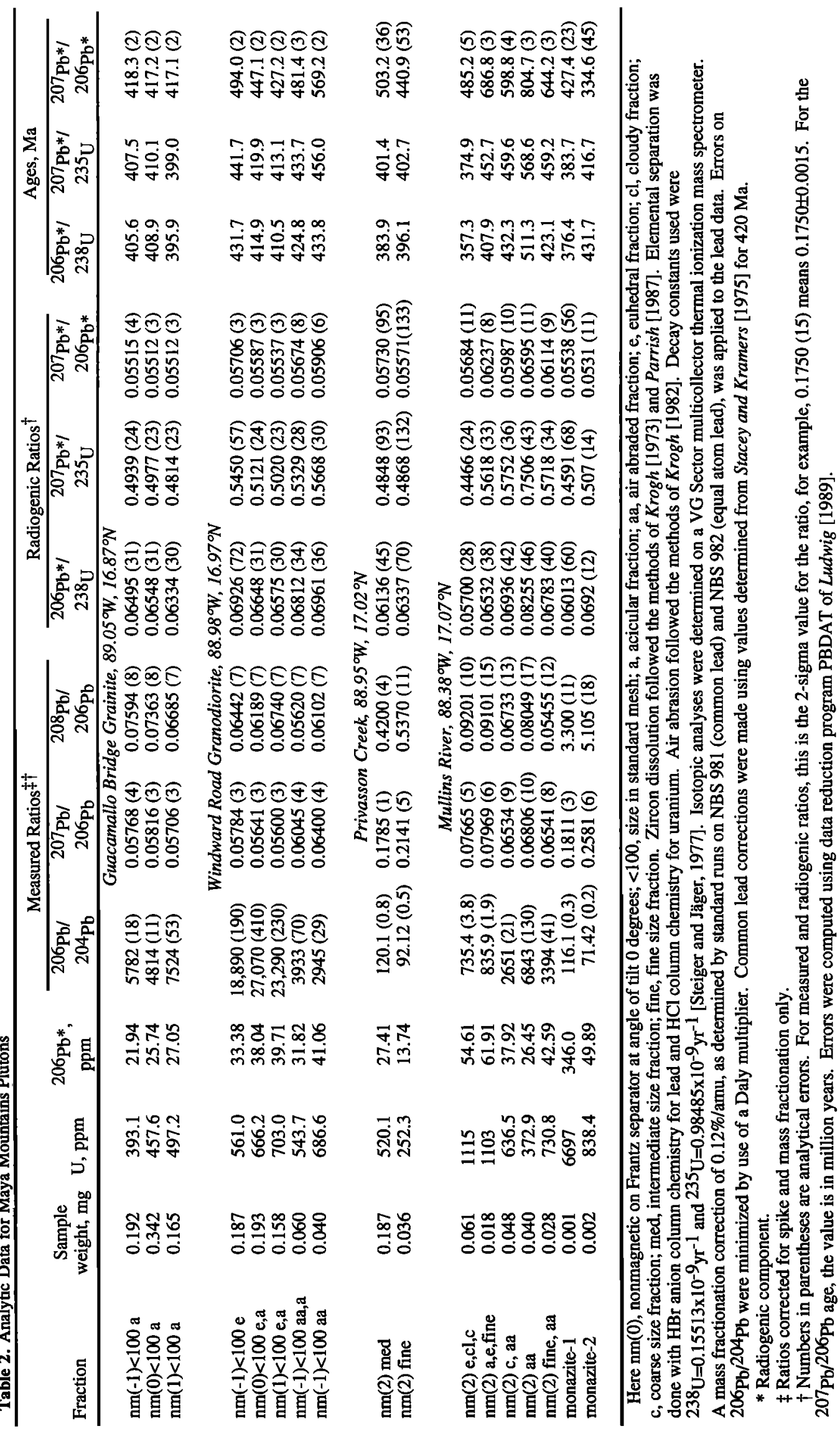



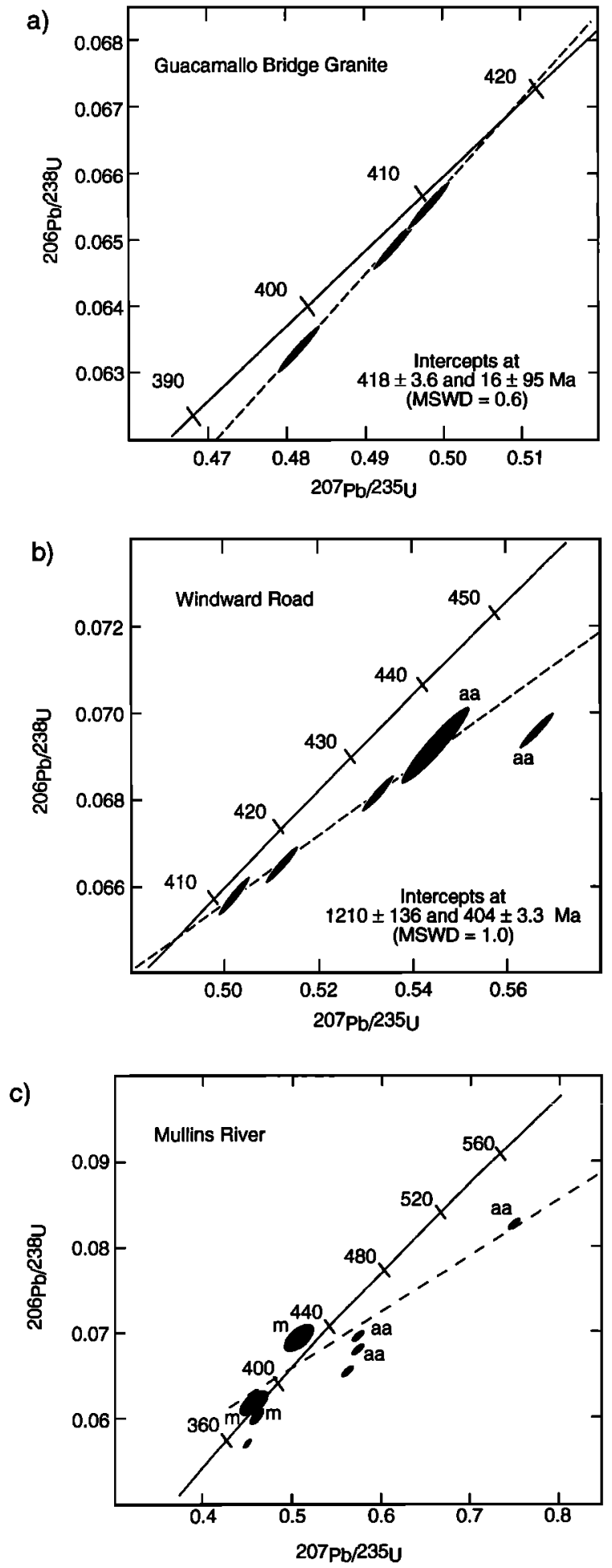

Figure 2. Concordia diagrams for U-Pb analyses. All fits are model 1 of Ludwig [1990]. MSWD denotes mean square of weighted deviates.

show that at least a portion of the HMR pluton was not intruded in Late Triassic time as is widely believed [Bateson and Hall, 1977; Shipley, 1978; Dawe, 1984; Donnelly et al., 1990]. Because the localities sampled for U-Pb dating in the MPR and HMR plutons were the same localities from which the 230-Ma $\mathrm{K}$-Ar ages had been obtained, it is therefore evident that these Late Triassic ages do not represent crystallization ages, and that the 230-Ma event probably was not an intrusive episode. This evidence and the uniformity of the K-Ar ages throughout the Maya Mountains lead us to conclude that all the 230-Ma ages of the Maya Mountains represent a resetting/cooling event and not an intrusive episode.

The 230-Ma event recorded in the igneous rocks most likely represents the breakup of Pangea and initial rifting that formed the Gulf of Mexico. Current Pangean reconstructions place the Yucatan Block within the Gulf of Mexico, adjacent to southern North America and northern South America [e.g., Pindell, 1985; Schouten and Klitgord, 1994]. The rifting which separated North America from Africa during the breakup of Pangea is about the same age as the 230-Ma event in Belize, because the oldest sedimentary rocks filling the rift basins of eastern North America are Carnian in age [Cornet, 1993]; by current timescales, $230 \mathrm{Ma}$ is about the middle of the Carnian [e.g., Harland et al., 1990]. Since the Late Triassic ages in two of the Maya Mountains plutons do not represent crystallization ages, and since the Maya Mountains and Yucatan Block are thought to have been located in the former region of the Gulf of Mexico prior to Pangean breakup, it is logical that those $\mathrm{K}-\mathrm{Ar}$ ages reflect heating associ-ated with Pangean rifting.

In the MPR pluton, the Late Triassic ages have been linked to the episode of hydrothermal activity [Dawe, 1984]; this association and the occurrence of Late Triassic K-Ar ages throughout the Maya Mountains suggests that the hydrothermal event could have been more widespread than just the vicinity of the MPR pluton and may constitute the 230-Ma thermal event.

\section{Origin of the Contact Metamorphism}

A hydrothermal origin for the 230-Ma event would resolve a dilemma which is posed by the presence of apparent contact metamorphosed sedimentary rocks in direct contact with the granite we sampled in the Mullins River pluton and for which we obtained obtained a Late Silurian $\mathrm{U}-\mathrm{Pb}$ age. The adjacent sedimentary rocks clearly are described as contact metamorphosed [Ower, 1928; Dixon, 1956; Bateson and Hall, 1975, 1977]; those sedimentary rocks were sampled for paleomagnetic study [Steiner, 1996] at the same time as the radiometric samples were collected and definitely appear to be more altered than other Santa Rosa strata sampled for paleomagnetic investigation.

The presence of Late Silurian granite in contact with contactmetamorphosed Pennsylvanian-Permian sedimentary rocks necessitates a reconsideration of the nature of the alteration of the sedimentary rocks at these pluton margins. Reconsideration of the origin of the alteration also is required by the strong probability that all Maya Mountains plutons are older than the enclosing sedimentary strata. Three explanations are possible: (1) The sediments around the eastern plutons are contact metamorphosed Pennsylvanian-Permian Santa Rosa Group and the $\mathrm{U}-\mathrm{Pb}$ (HMR pluton) and the single $\mathrm{Rb}-\mathrm{Sr}$ ( $\mathrm{C} / \mathrm{S}$ pluton) dates are incorrect; (2) the U-Pb date of the HMR pluton is correct and the pluton is older than Santa Rosa sedimentation, but the sedimentary rocks adjacent to the pluton are not the Pennsylvanian-Permian Santa Rosa Group but an earlier sedimentary sequence which was contact metamorphosed during Late Silurian intrusion of the pluton into that sedimentary sequence; or (3) the thermal alteration is not contact metamorphism but the result of a hydrothermal event whose fluids were channeled along the plutonic/sedimentary contacts.

The possibility that the HMR date is grossly in error due to $\mathrm{Pb}$ loss or inheritance is unlikely. Although both the monazite 
and zircon fractions indicate complex U-Pb systematics, the three monazite fractions cluster around concordia at approximately $400 \mathrm{Ma}$; they may reflect varying degrees of younger $\mathrm{Pb}$ loss. The five zircon fractions yield a nonlinear array that trends from 1600 to $410 \mathrm{Ma}$ and are consistent with a mixture of inherited zircons and those formed during crystallization of the pluton at about $410 \mathrm{Ma}$ to $420 \mathrm{Ma}$ (oldest monazite). Hence, both mineral systems only indicate ages consistent with an age near 410$420 \mathrm{Ma}$, not the $230 \mathrm{Ma}$ age that has been associated with the contact metamorphism.

The second possibility, that the contact-altered sedimentary rock is not the Santa Rosa Group but an older sedimentary rock contact metamorphosed during intrusion at an earlier time, cannot be ruled out, particularly because detailed descriptions of the contact metamorphosed rocks are not given in the literature, and no similar Santa Rosa strata were sampled in the reconnaissance paleomagnetic study [Steiner, 1996]. The chiastolite in the contact-metamorphosed rocks is reported as altered [Dixon, 1956; Bateson, 1972], a fact which might be viewed as support for the concept that these sediments are pre-Santa Rosa Group; however, the multiple events in the geologic history of this area permit numerous opportunities for that alteration to have occurred.

The third possibility, that the alteration results from a Late Triassic hydrothermal event, also is permissible. Two items were the major evidence that the alteration around the eastern plutons was contact metamorphism: one was its confinement to the contacts and the other was the presence of chiastolite (andalusite) [Dixon, 1956; Bateson and Hall, 1977]. Abundant tourmaline also had been observed in the thermal aureoles [Bateson and Hall, 1977]. A strict interpretation of the mineralogy of this contact alteration allows the possibility of either a contact-metamorphic or a hydrothermal origin.

In addition to its formation within contact-metamorphic pressure/temperature regime, andalusite also can be generated under the hydrothermal conditions as well [Rose and Burt, 1979; Barnes, 1979]. Therefore, the presence of andalusite, while highly suggestive, is not unequivocal evidence of contact metamorphism. Furthermore, tourmaline is a common hydrothermal mineral; it was the principal indicator of the presence of hydrothermal alteration around the northwest pluton (observed both in hydrothermally altered plutonic as well as sedimentary rocks) [Dawe, 1984]. The fact that both the hypothesized contact-metamorphic and the hydrothermal alterations share an abundance of authigenic tourmaline suggests the possibility of a common origin.

Also, the patterns of the alteration around the eastern plutons and the western pluton are similar. Like the hypothesized contact-metamorphic alteration eastern plutons, the hydrothermal alteration around the western pluton also is confined to the margins of the pluton [Dawe, 1984]. Hence the main difference between the eastern and western contact alterations appears to be the presence and abundance of andalusite around the eastern plutons and not the western. The fact that andalusite can be formed under hydrothermal conditions allows the possibility that the eastern contact metamorphism also might be a hydrothermal alteration, perhaps generated at higher temperature conditions. Moreover, hydrothermal alteration is not restricted to the MPR pluton; Cole and Andrews-Jones [1979] reported numerous observations of hydrothermal alteration in association with the southern volcanic complex and summarized other such observations by Flanders [1978], Thoreson [1980], and Druecker [1978]. Furthermore, the $230 \mathrm{Ma} \mathrm{K}-\mathrm{Ar}$ dates also have been reported from that volcanic complex. All of these considerations and the uniformity of the $230 \mathrm{Ma} \mathrm{K}-\mathrm{Ar}$ ages suggests the occurrence of a widespread hydrothermal event in the Maya Mountains.

Finally, the density and textural contrasts between the finegrained, low-porosity pelitic Santa Rosa sediments and the medium to coarse grained granitic plutonic rocks reasonably could have caused the pluton margins to serve as conduits for hydrothermal fluids. If the contact metamorphism of the eastern plutons is a hydrothermal alteration, the mineralogical differences between it and the marginal alteration around the western pluton possibly might be related to a difference in structural level. The westerly dip of the Santa Rosa synclinorium [e.g., Bateson and Hall, 1977] may suggest that the Maya Mountains block has been tilted to the west, thus exposing deeper crustal levels in the east and a higher temperature regime of the hydrothermal activity.

\section{Relationship to Other Age Data}

Only a few radiometric data previously existed for the Yucatan Block or Central America as a whole. The new U-Pb ages thus significantly enhance the available data set. Despite the paucity of data, an age similar to our ages was reported from the northern Yucatan Block. A well, Yucatan-1, cored through Tetiary and Cretaceous rocks, terminated in a rock described variously as "rhyolite" or "rhyolite porphyry"; Rb-Sr measurements on the rhyolite suggested an age of $410 \mathrm{Ma}$ [LopezRamos, 1975]. This Rb-Sr age is similar to the $428 \pm 41 \mathrm{Ma} \mathrm{Rb}-$ Sr age from the Maya Mountains Sapote stock, as well as to our 400-420 Ma U-Pb ages.

Previously, the Early Carboniferous Rb-Sr age for the MPR pluton [Bateson and Hall, 1977] had appeared to be supported by a similar $\mathrm{U}-\mathrm{Pb}$ date from the Rabinal granite in adjacent Guatemala. The Rabinal granite resides among sedimentary rocks of similar lithologies as the Santa Rosa sediments of the Maya Mountains [McBimey, 1963], and a U-Pb date of $345 \pm 20$ Ma had been obtained [Gomberg et al., 1968]. However, the Late Silurian U-Pb dates for the MPR from the present study indicate that the similarity of ages was fortuitous and a function of a disturbed $\mathrm{Rb}-\mathrm{Sr}$ system in the MPR granite, as Bateson and Hall [1977] had surmised.

The Late Silurian U-Pb ages from the Maya Mountains plutons are similar to those of a small population of shocked zircons associated with the Chicxulub impact structure. The $\mathrm{K} / \mathrm{T}$ boundary Chicxulub impact structure is located on the northern end of the Yucatan Block. Shocked zircons from both the impact breccia within the Chicxulub structure and from the fallout layer in North America and Haiti (the $\mathrm{K} / \mathrm{T}$ boundary clay) show two groups of ages: The majority of the zircons are $544.5 \pm 5 \mathrm{Ma}$, but a population of $418 \pm 6 \mathrm{Ma}$ also is present [Krogh et al., 1993]. The $\geq 404-418$ Ma pluton ages of the present study indicate that, although the Maya Mountains are $460 \mathrm{~km}$ from Chicxulub, Late Silurian plutons may be a significant component of the basement of the Yucatan Block. Plutons coeval with those dated in the Maya Mountains provide an obvious source for the 418-Ma shocked zircons associated with the Chicxulub impact. Hence our Maya Mountains radiometric data add to the little that is known of the basement target rocks impacted at the Chicxulub site.

Finally, the Late Silurian age of the Maya Mountains plutons is the same as the age associated with the Acadian orogeny of eastern North America (and the Caledonian and Scandian orogenies of Europe). During the existence of Pangea, the Yucatan Block has been postulated to have been located just 
south of the Ouachita orogenic belt [e.g., Pindell, 1985; Pindell and Barrett, 1990; Schouten and Klitgord, 1994]. These reconstructions locate the Maya Mountains plutons to the south of Texas-Louisiana. The similarity of the $400-420 \mathrm{Ma}$ ages of this study to the numerous circa $400-415 \mathrm{Ma}$ ages of the Carolinas [e.g., Kish, 1990] suggests the possibility of a continuation of the southern Appalachian Acadian-age orogeny along the southern border of the North American craton. The Late Silurian ages could indicate either that the Maya Mountains and Yucatan Block were part of the Africa-South America continental mass prior to Pangean breakup or that the trend of the Acadian orogeny continues into South America, perhaps along a trend similar to that suggested for the earlier Taconic orogeny [Dala-Salada, et al., 1992].

\section{Summary and Conclusions}

Late Silurian $\mathrm{U}-\mathrm{Pb}$ ages were obtained from two the three Maya Mountains plutons. Both give ages which predate the enclosing Late Pennsylvanian to mid-Permian Santa Rosa sedimentary strata, previously thought to have been intruded by the plutonic rocks of the Maya Mountains. Three of the five compositional phases of the northwestern Mountain Pine Ridge pluton yield predepositional Late Silurian ages of 404 to $418 \mathrm{Ma}$, and the presence of abundant sandstone, conglomerate, and red bed sedimentary facies at the pluton margins indicate that this igneous body was emergent during Santa Rosa sedimentation. The northeastern Hummingbird-Mullins River pluton, thought to have been intruded during the Late Triassic because of abundant $230 \mathrm{Ma} \mathrm{K}-\mathrm{Ar}$ ages and marginal alterations at the pluton contacts, gave a U-Pb age of about $410-420 \mathrm{Ma}$, also predating Santa Rosa deposition. The third of the three Maya Mountains plutons, the southeastern Cockscomb pluton, was not dated in this reconnaissance study, but coarse sedimentary facies, some possible red-bed strata, and a single $\mathrm{Rb}-\mathrm{Sr}$ age of $428 \pm 41$ suggest that this pluton probably also is older than the enclosing Pennsylvanian-Permian sedimentary rocks and may have been emergent during their deposition.

The new U-Pb ages of this study call into question the widely held belief that much of the plutonic intrusion in the Maya Mountains occurred in the Late Triassic. The widespread $\mathrm{K}-\mathrm{Ar}$ ages of about $230 \mathrm{Ma}$ are present in the same localities which yield Late Silurian $\mathrm{U}-\mathrm{Pb}$ ages. Moreover, the Late Silurian age from the northeastem pluton is derived from granite in immediate contact with the contact-altered sedimentary country rock, indicating that the alteration at this locality is not contact metamorphism. The new ages and some similarities of the contact alteration surrounding the eastern plutons with a hydrothermal alteration adjacent to the margins of the western pluton suggest that the thermal alteration marginal to all plutons might be of hydrothermal origin. Because the $\mathrm{U}-\mathrm{Pb}$ ages indicate that intrusion in the Maya Mountains region did not occur during the Late Triassic, the uniform widespread Late Triassic K-Ar ages probably represent the breakup of Pangea, perhaps a hydrothermal signature of the rifting that formed the Gulf of Mexico.

The Late Silurian ages of the Maya Mountains plutons are the same age as the smaller of two populations of shocked zircons associated with the Chicxulub K/T boundary impact [Krogh et al., 1993], suggesting that the Maya Mountains exposures probably are widely representative of the Yucatan basement and of the basement rock impacted by the Chicxulub bolide.

Acknowledgments. Initial, pilot funding for this study was provided by NSF (EAR-9019094). Discussions with Ron Frost and Art Snoke im- proved the concepts presented in this manuscript and are gratefully acknowledged.The Belize Ministry of Geology and its director, Evadine Garcia, were especially helpful with the logistics of this study and generous with the Ministry facilities, for both of which we are deeply grateful.

\section{References}

Barnes, H.L., , Geochemistry of Hydrothermal Ore Deposits, 2nd ed., John Wiley, New York, p. 175, 1979.

Bateson, J.H., New interpretation of geology of Maya Mountains, British Honduras, Am. Assoc. Pet. Geol. Bull., 56, 956-963, 1972.

Bateson, J.H., and I.H.S. Hall, Geological map of the Maya Mountains, Belize, Nat. Environ. Res. Counc., Her Majesty's Ord. Surv., London, 1975.

Bateson, J.H., and I.H.S. Hall, The Geology of the Maya Mountains, Belize, Inst. Geol. Sci. Overseas Mem., 3, Her Majesty's Stationery Office, London, 42 pp., 1977.

Cole, G.L., and D.A. Andrews-Jones, Geological and economic evaluation including exploration results of the 1978 field season, Belize Ann. Rep., 4. 37 p., Belize Minist. of Geol., Belmopan, 1979.

Comet, B., Applications and limitations of palynology in age, climatic, and paleoenvironmental analyses of Triassic sequences in North America, $N$. M. Mus. Nat. Hist. and Sct. Bull., 3, 75-93, 1993.

Dala-Salda, L.H., I.W.D. Dalziel, C.A. Cingolani, and R. Varela, Did the Taconic Appalachians continue into southern South America?, Geology. 20, 1059-1062, 1992.

Dawe, S.E., The geology of the Mountain Pine Ridge area and the relation of the Mountain Pine Ridge granite to the Late Paleozoic and Early Mesozoic geological history of Belize, Central America, Ms. thesis, 52 p., State Univ. N. Y. Binhamton, Binghamton, 1984.

Dengo, G., and Bohnenberger, $O$., Structural development of northem Central America, Am. Assoc. Pet. Geol. Mem., 11, 203-220, 1969.

Dixon, C.G., Geology of Southern British Honduras, With Notes on Adjacent Areas, 85 p., Belize Govt. Printer, Belmopan, 1956.

Donnelly, T.W., G.S. Horne, R.C. Finch, E. Lopez-Ramos, Northern Central America; The Maya and Chortis blocks, in The Geology of North America, vol. H, The Caribbean Region, edited by G. Dengo, and J.E. Case, pp. 37-76, Geo. Soc. of Am., Boulder, Colo., 1990.

Druecker, M.D., The geology of the Bladen Volcanic Series, southem Maya Mountains, Belize, Central America, Ms. thesis, 73 pp., Colo. School of Mines, Golden, 1978.

Flanders, R.W., Geology of the Chiquibul area, Belize, Central America, Ms. thesis, 62 pp., Univ. of Idaho, Moscow, 1978.

Gomberg, D.N., P.O. Banks, and A.R. McBiney, Guatamala: Preliminary zircon ages from central cordillera, Science, I62, 121-122, 1968.

Hall, I.H.S., and Bateson, J.H., Late Paleozoic lavas in Maya Mountains, British Honduras and their possible regional significance, Am. Assoc. Pet. Geol. Bull., 56. 950-963, 1972.

Harland, W.B., R.L. Armstrong, A.V. Cox, L.E. Craig, A.G. Smith, and D.G. Smith, A Geologic Time Scale 1989, 263 pp., Cambridge Univ. Press, Cambridge, 1990.

Kesler, S.E., J.H. Bateson, W.L. Josey, G.H. Cramer, and W.A. Simmons, Mesoscopic structural homogeneity of Maya Series and Macal Series, Mountain Pine Ridge, British Honduras, Am. Assoc. Pet. Geol. Bull., 55, 97-103, 1971.

Kesler, S.E., C.F. Kienle, and J.H. Bateson, Tectonic significance of intrusive rocks in the Maya Mountains, British Honduras, Geol. Soc. Am. Bull., 85, 3307-3322. 1974.

Kish, S.A., Timing of the middle Paleozoic (Acadian) metamorphism in the southern Appalachians: K-Ar studies in the Talladega belt, Alabama, Geology, 18, 650-653, 1990.

Krogh, T.E., A low contamination method for hydrothermal decomposition of zircon and extraction of $\mathrm{U}$ and $\mathrm{Pb}$ for isotopic age determinations, Geochim. Cosmochim. Acta, 37, 485-494, 1973.

Krogh, T.E., Improved accuracy of U-Pb ages by the creation of more concordant systems using an air abrasion technique, Geochim. Cosmochm. Acta, 46, 637-649, 1982.

Krogh, T.E., S.L. Kamo, B. Sharpton, L. Marin, and A.R. Hildebrand, $\mathrm{U}-\mathrm{Pb}$ ages of single shocked zircons linking distal $\mathrm{K} / \mathrm{T}$ ejecta to the Chicxulub crater, Nature, 366, 731-734, 1993.

Lopez-Ramos, E., Geological summary of the Yucatan Peninsula, in The Ocean Basıns and Margins, edited by A.E.M. Nairn, and F.G. Stehli, Plenum, New York, pp. 257-282, 1975.

Ludwig, K.R., PBDAT for MS-DOS: A computer program for IBM-PC compatibles for processing raw $\mathrm{Pb}-\mathrm{U}-\mathrm{Th}$ isotope data, version 1.06, U.S. Geol. Surv. Open File Rep., 88-542, 40, 1989. 
Ludwig, K.R., ISOPLOT: A plotting and regression program for radiogenic-isotope data, for IBM-PC compatible computers version 2.02, U.S. Geol. Surv. Open File Rep., 88-557, 44, 1990.

Massachusetts Institute of Technology, Variations in isotopic abundances of strontium, calcium, and argon and related topics, 16th Annual Progress Report, U.S. Atomic Energy Commission Contract AT (30-1)-1381-16, pp. 79-80, 1968.

McBimey, A.R., Geology of a part of the central Guatemalan cordillera, Univ. Calif. Publ. Geol. Sci., 39 (4). 177-242, 1963.

Muncaster, N., Mineral reconnaissance of granites in the Maya Mountains, Belize, C.A., Anschutz Minerals Corp. report, 20 pp., 1976.

Ower, L.H., Geology of British Honduras, J. Geol., 36, 494-509, 1928.

Parrish, R.R., An improved mucro-capsule for zircon dissolution in U-Pb geochronology, Chem. Geol., 66, 99-102, 1987.

Paterson, S.R., and $O \mathrm{~T}$ Tobisch, Using pluton ages to date regional deformations: Problems with commonly used criteria, Geology, 16, 1108$1111,1988$.

Pindell, J., Alleghenian reconstruction and subsequent evolution of the Gulf of Mexico, Bahamas and proto-Caribbean, Tectonics, 4, 1-39, 1985.

Pindell, J.L., and Barrett, S.F.and Geological Evolution of the Caribbean Region: A plate-tectonic perspective, in The Geology of North America, vol. H, The Caribbean Regıon, edited by G. Dengo, and J.E. Case, pp. 405432, Geo. Soc. of Am., Boulder, Colo., 1990.

Rose, A.W., and D.M. Burt, Hydrothermal alteration, in Geochemistry of Hydrothermal Ore Deposits, edited by H.L. Barnes, pp. 173-235, John Wiley, New York, 1979.

Ross, C.A., Late Paleozoic collision of North and South America, Geology, 7, 41-44, 1979.
Schouten, H., and K.D. Klitgord, Mechanistıc solutions to the opening of the Gulf of Mexico, Geology. 22, 507-510, 1994

Shipley, W.E., III, Geology, petrology and geochemistry of the Mountain Pine Ridge batholith, Belize, Central America, Ms. thesis, 90 pp., Colo. School of Mines, Golden, 1978.

Simnons, W.A., Stratigraphy and sedimentation of the Paleozolc rocks in the Maya Mountains, British Honduras, Ms. thesis, 87 pp., La. State Univ., Baton Rouge, 1972

Stacey, J.S., and J.D. Kramers, Approximation of terrestrial lead isotope evolution by a two-stage model, Earth Planet. Scr. Lett., 26, 207-22 1, 1975.

Steiger, R.H., and E. Jaeger, Subcommission on geochronology; convention on the use of decay constants in geo- and cosmochronology. Earth Planet. Sci. Lett., 36. 359-362, 1977.

Steiner, M.B., Yucatan paleomagnetic data indicate clockwise rotatıon, Geophys. J. Int., in press, 1996.

Thoreson, R.F., Reconaissance geology of the westem Smokey, Cerbo Grande and Ceibo Chico Rivers, Belize, Central Anerica, Ms. thesis, 69 pp, Univ. of Idaho, Moscow, 1980.

M.B. Steiner, Department of Geology and Geophysics, University of Wyoming, Laramie, WY 82071. (e-mail: magnetic@uwyo.edu)

J.W. Walker, Isotope Geochemistry Laboratory and Department of Geology, University of Kansas, Lawrence, KS 66054. (E-mail: jdwalker@kuhub.cc.ukans.edu)

(Received January 30, 1995; revised October 30, 1995; accepted January 9, 1996) 